International Journal of Trend in Scientific Research and Development (IJTSRD)

Volume: 3 | Issue: 4 | May-Jun 2019 Available Online: www.ijtsrd.com e-ISSN: 2456 - 6470

\title{
A Result Paper on Experimental Study on Stabilization of Soil Subgrade by Adding Stone Dust
}

\author{
Deepak Kumar' ${ }^{1}$ Magandeep Bishnoi ${ }^{2}$ \\ ${ }^{1}$ M.Tech Scholar, ${ }^{2}$ Assistant Professor \\ 1,2Department of Civil Engineering, Om Institutes of Technology \& Management, Juglan Hisar, Haryana, India
}

\begin{abstract}
How to cite this paper: Deepak Kumar | Magandeep Bishnoi "A Result Paper on Experimental Study on Stabilization of Soil Subgrade by Adding Stone Dust" Published in International Journal of Trend in Scientific Research and Development

(ijtsrd), ISSN: 2456-

6470, Volume-3 |

Issue-4, June 2019, pp.1065-1071, URL: https://www.ijtsrd.c om/papers/ijtsrd24 044.pdf

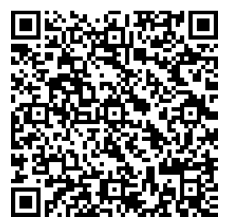

IITSRD24044
\end{abstract}

Copyright (C) 2019 by author(s) and International Journal of Trend in Scientific Research and Development Journal. This is an Open Access article distributed under the terms of the Creative Commons

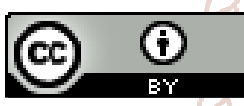
Attribution License (CC BY 4.0) (http://creativecommons.org/licenses/ by $/ 4.0$ )

\section{INTRODUCTION}

Transport is need of human being from ancient time to fulfill all needs which may otherwise cant fulfilled. For development of civilization transportation is must as trade Is not possible without effective transportation system. There are various mode of transportation from one place to other which includes Road, railway, airways, canal, pipeline, water etc. It makes possible to use specific type of vehicle, operation and infrastructure. Highway pavement is hard, strong surface on which vehicle travels. It should be water permeable, even, friction on pavement should be reasonable because too less and too high friction cause problems. Soil Subgrade is lowermost layer of a highway;it is nothing but layer of natural soil over which other layers of pavement are placed Sub-base and Base courses these courses provide a medium to spread the wheel load to the subgrade. Boulder stone, brick on edge and stabilized are also used for sub base.

\section{ABSTRACT}

There are various technique for improving strength and CBR value of soil. But by this method lot of investment require. So we improved the strength of soil by De slurry of stone which contain lime. We find that when Kota Stone $13.80 \%$ to $19.70 \%$. Because in the Kota Stone Dust lime is available so lime absorb the water it moisture contain value increased. We also conclude that when Kota Stone Dust are added in the soil then maximum dry density will be are but after more than $4 \%$ Kota stone Dust are added then strength will not increased.

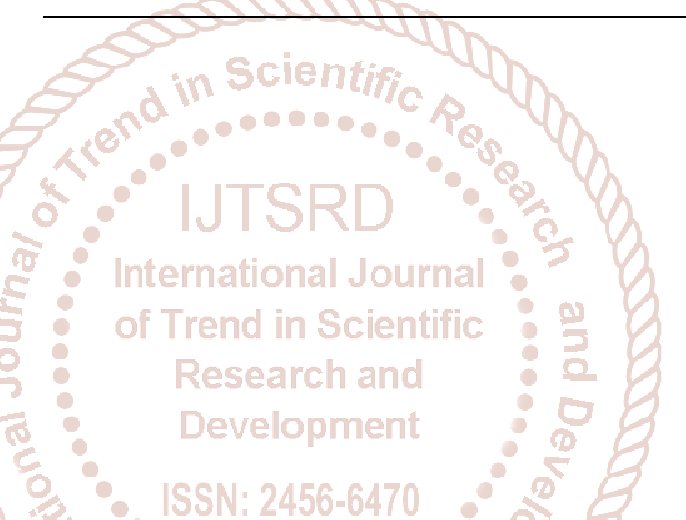

\section{Literature Review}

Soil stabilization is the old concept. Many studied carried out to soil stabilization by adding different mineral and admixture to improved the properties of soil.

Aakanksha Gautam and S.K, Mittal et al. (2018) Black cotton soil are expensive soil which are more shrinkage and swelling properties and not suitable for subgrade as well as foundation. So bagasse ash and coir fiber are added to improvement the properties.

Arun Kumar et al (2018) Soil subgrade can be improved by adding bituminous mixture. By adding this soil becomes more stable.

Chansoria et al. (2016) Studied improvement of Black cotton soil by adding of dust which are the waste material obtained by quarrying stone. Black cotton soil samples are blended with $10 \%, 20 \%, 30 \%$ and $40 \%$ of quarry dust were prepared and series of laboratory experiments have been performed. 
International Journal of Trend in Scientific Research and Development (IJTSRD) @ www.ijtsrd.com eISSN: 2456-6470

3. Experimental Programme:-

1. Compaction Test:-

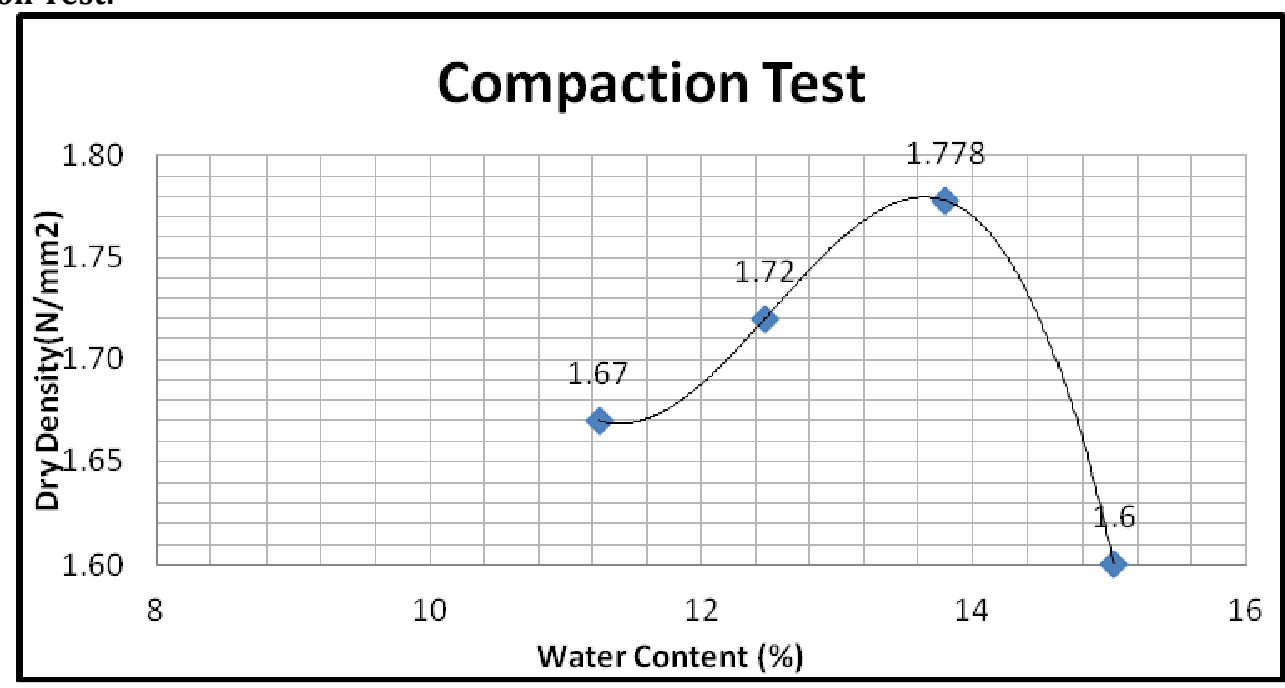

Graph: Water content and Dry Density

2. Liquid Limit Test Value:-

\section{L determination}

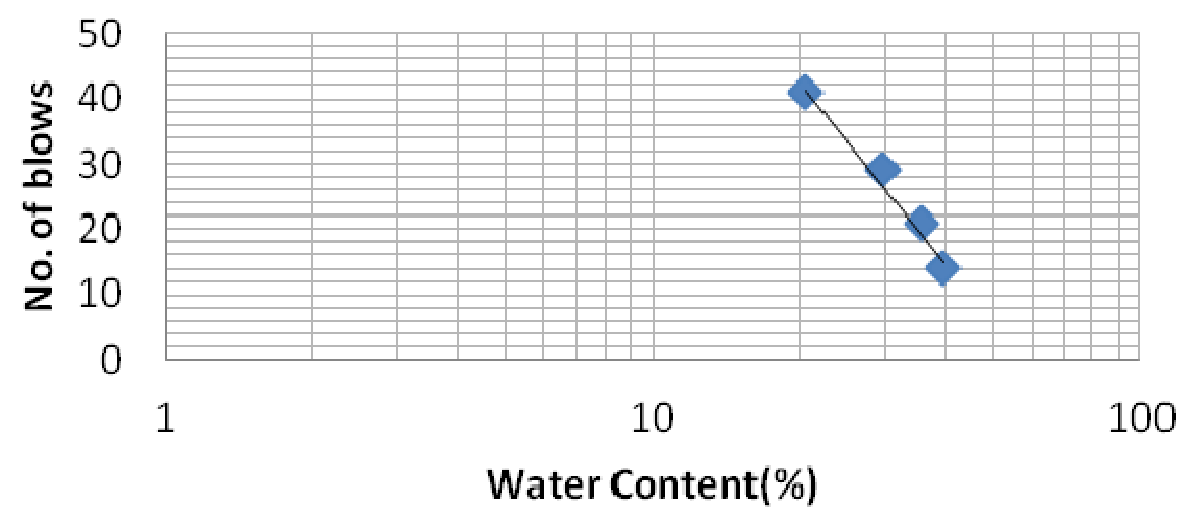

Graph: Water Content \&No. of Blows

3. Liquid Limit Test Value

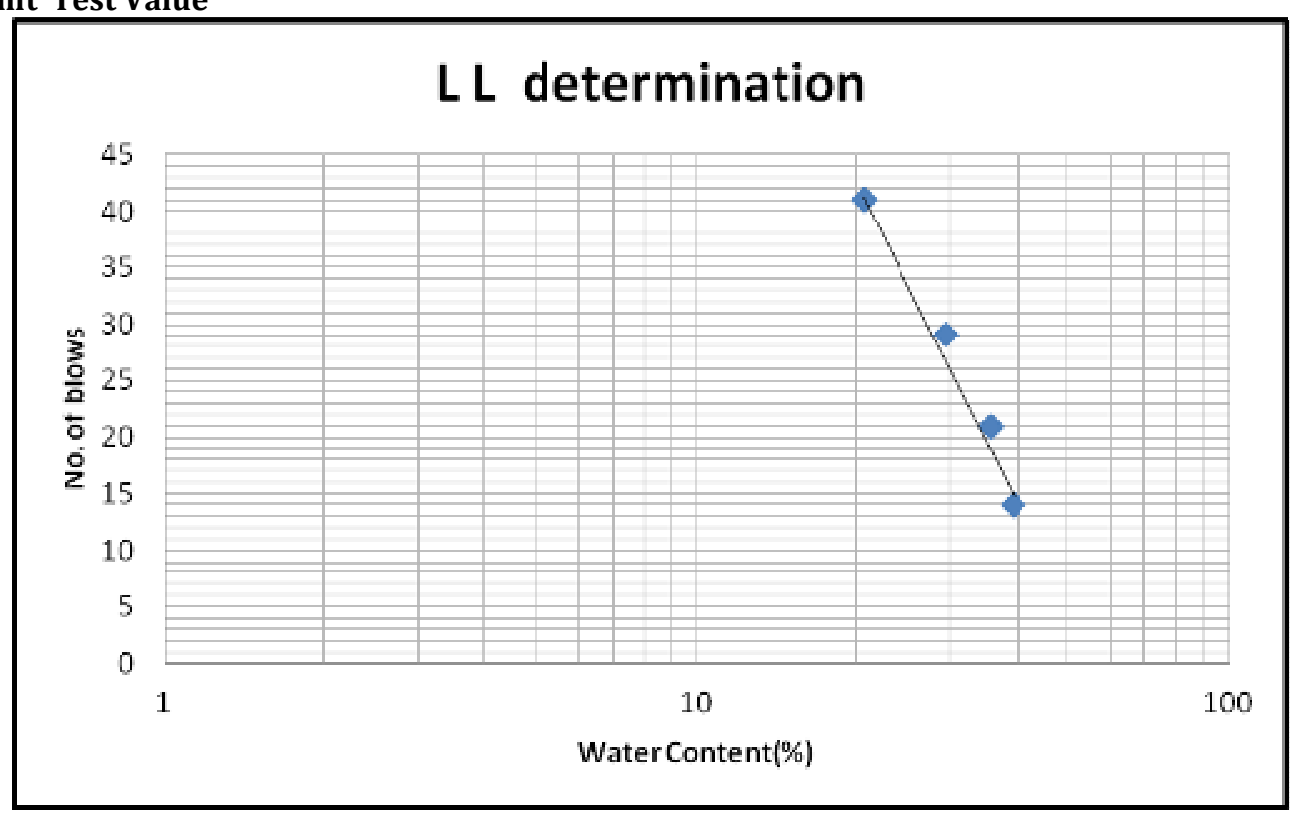

Graph: Water Content \&No. of Blows 
International Journal of Trend in Scientific Research and Development (IJTSRD) @ www.ijtsrd.com eISSN: 2456-6470

4. Grain Size Distribution:-

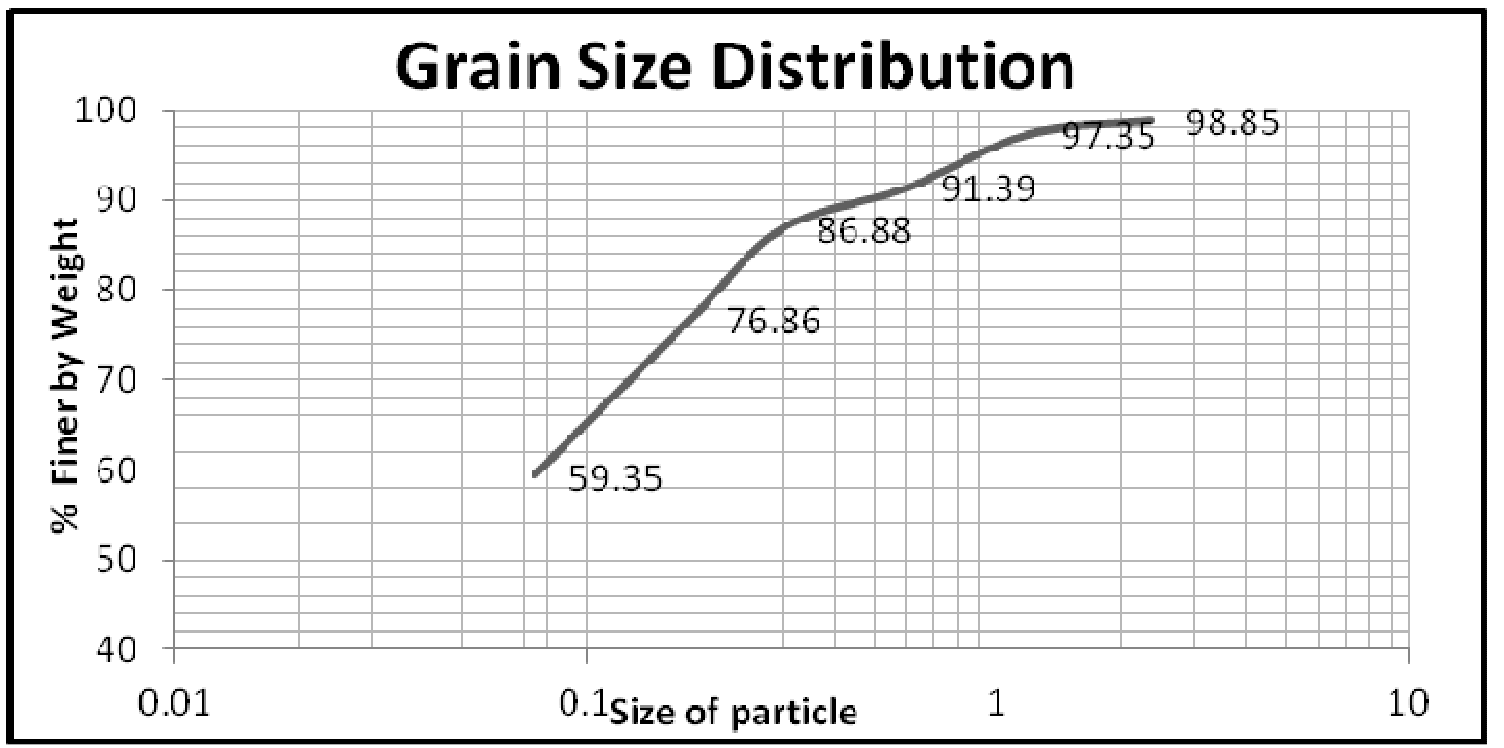

5. COMPACTION TEST OF MIX:-

I. For $2 \%$ Kota Stone Dust:

\section{Compaction Test}

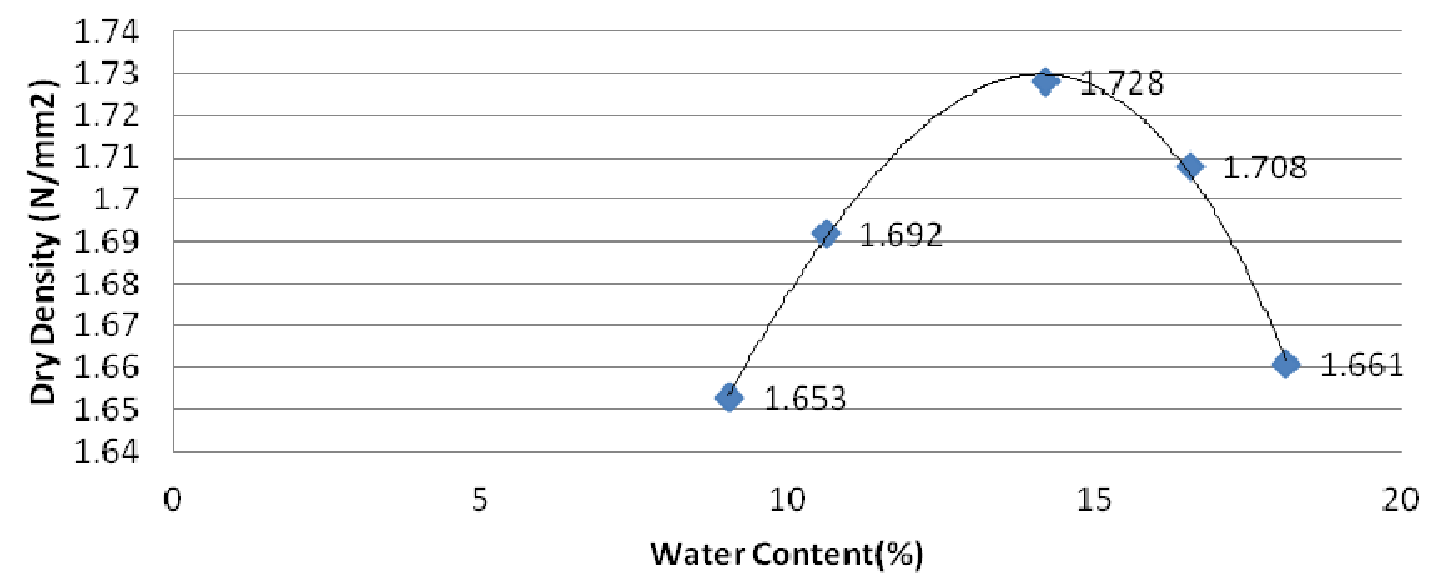

II. For 4\% Kota Stone Dust:-

\section{Compaction Test}

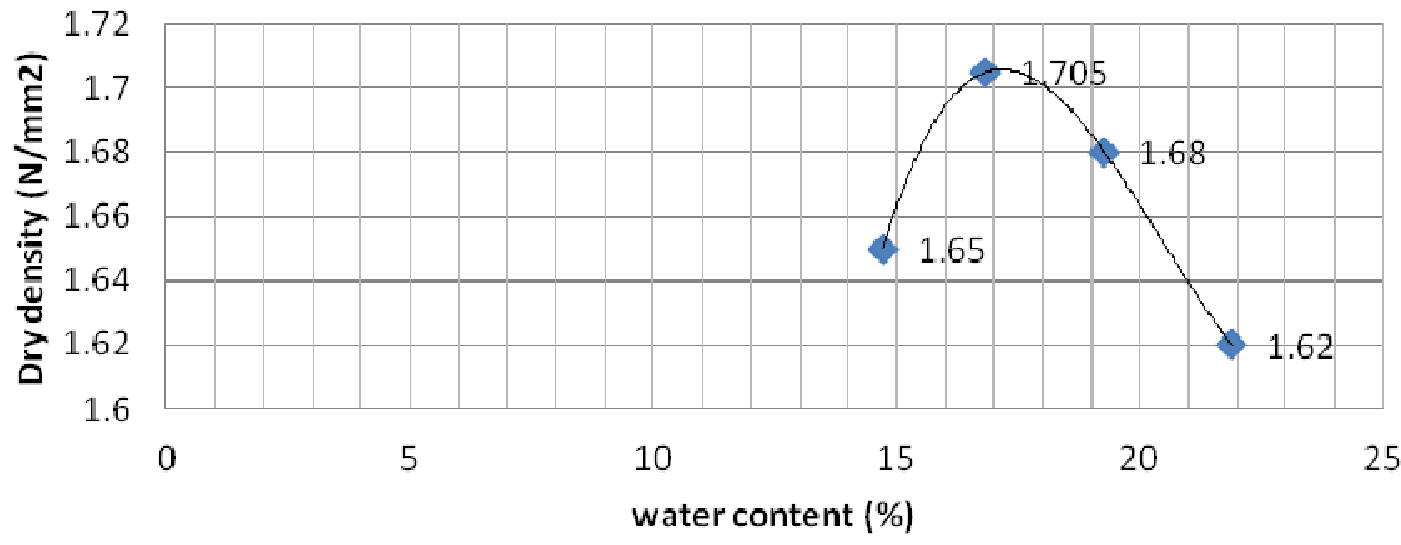

Graph: Between water content and Dry Density for 4\% KSD addition 
III. For 6\% Kota Stone Dust:-

\section{Compaction Test}

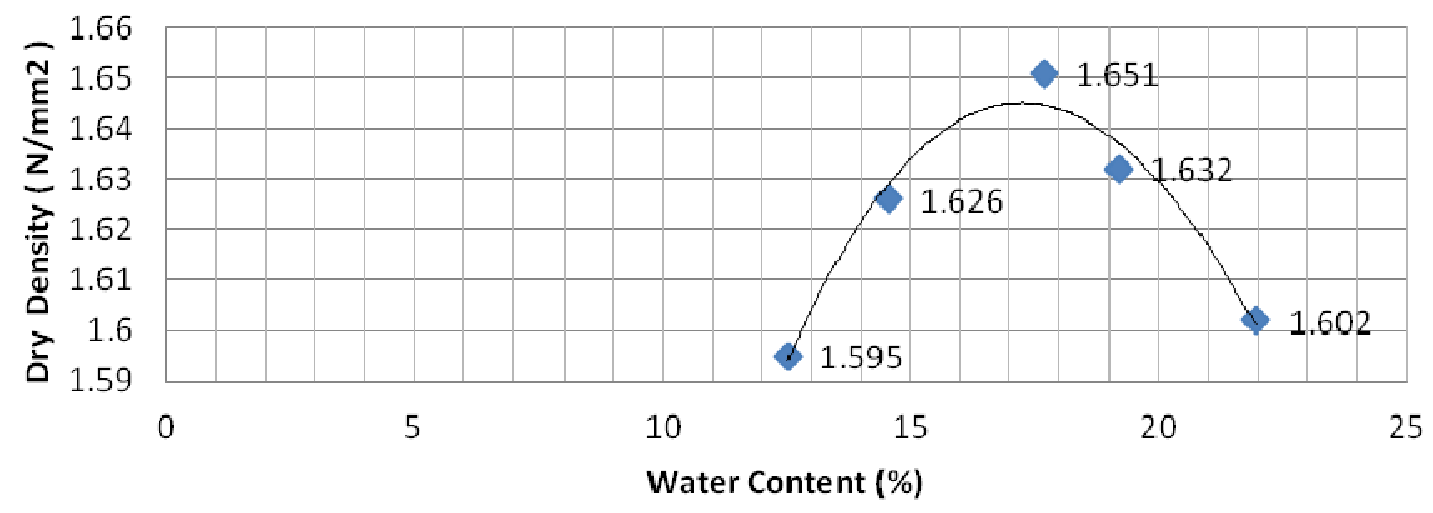

Graph:- water content and Dry Density for $6 \% \mathrm{KSD}$ addition

IV. For 8\% Kota Stone Dust

\section{Compaction Test}

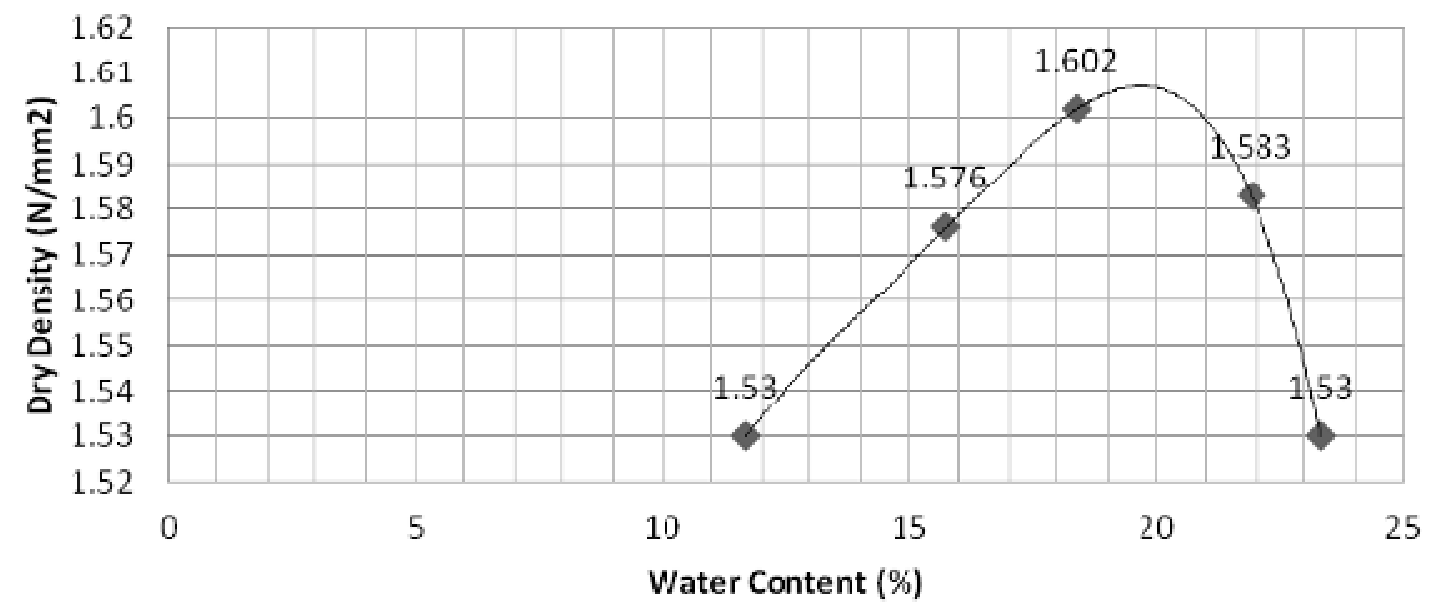

Graph:- Water content and Dry Density for 8\% KotaStone Dust

V. For $10 \%$ Kota Stone Dust

\section{Compaction Test}

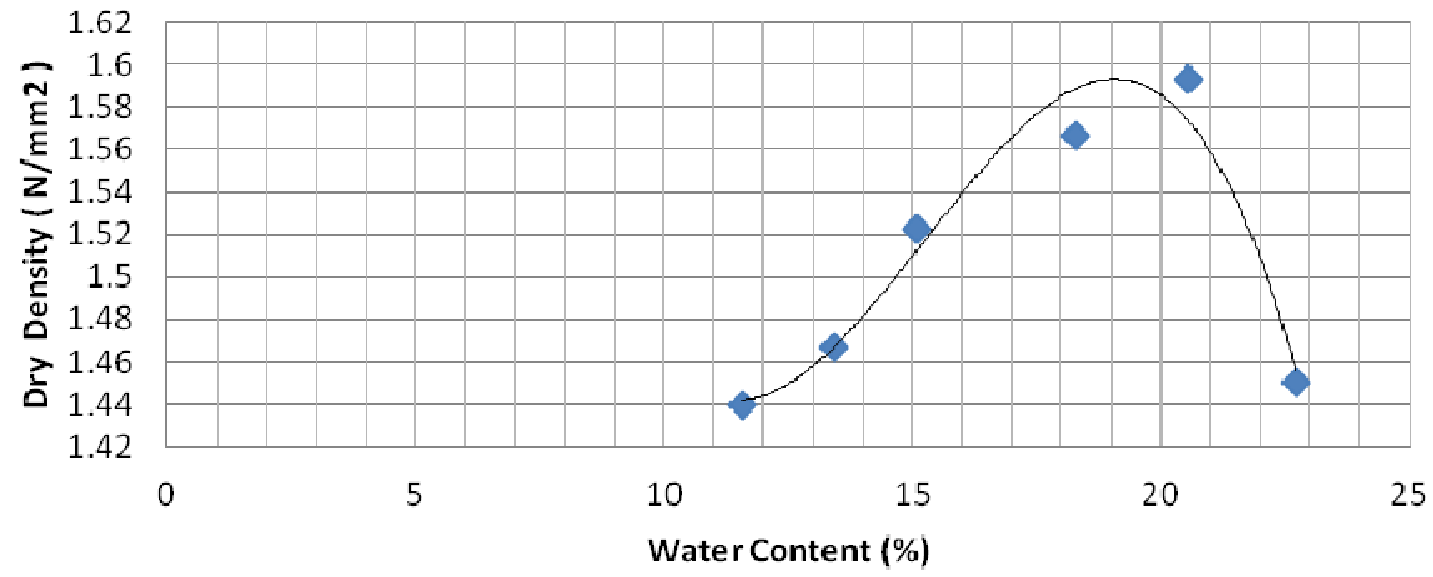

Graph:-Water Content and Dry Density for $10 \%$ Kota Stone Dust 
6. UNCONFINED COMPRESSION TEST:-

For 0 \% Kota Stone Dust:

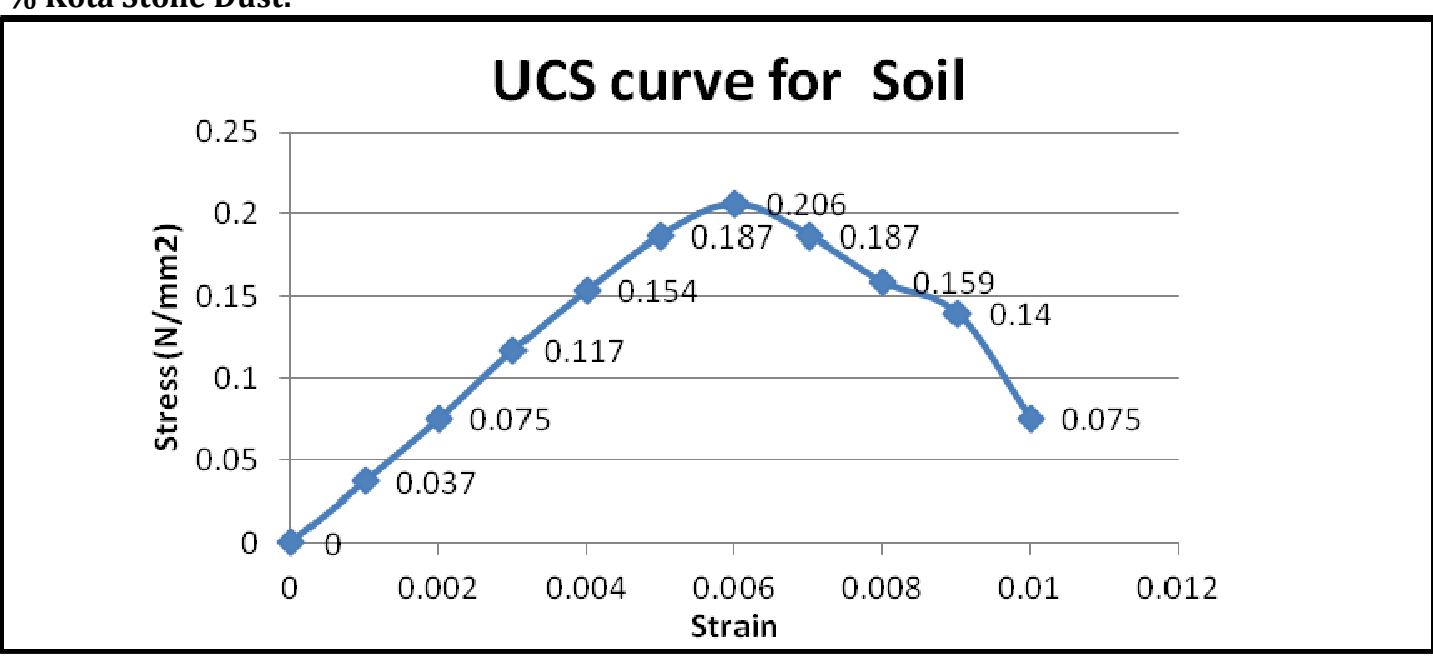

Graph:- Graph between Stress and Strain curve for UCS Test

I. For 2\%Kota Stone Dust:

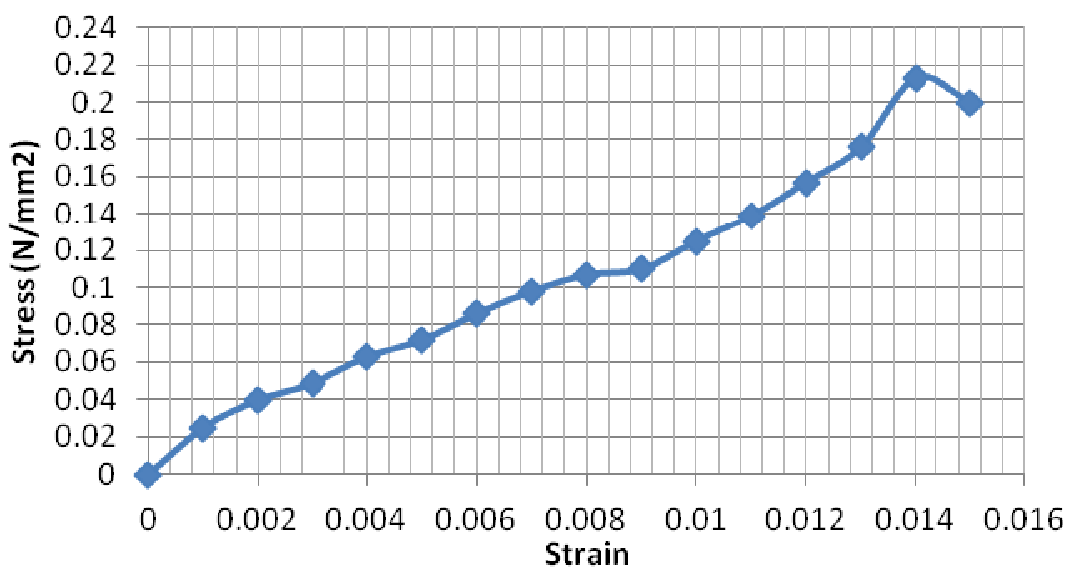

Graph: Stress and Strain in UCS Test (2\%)

II. For $4 \%$ Kota Stone Dust

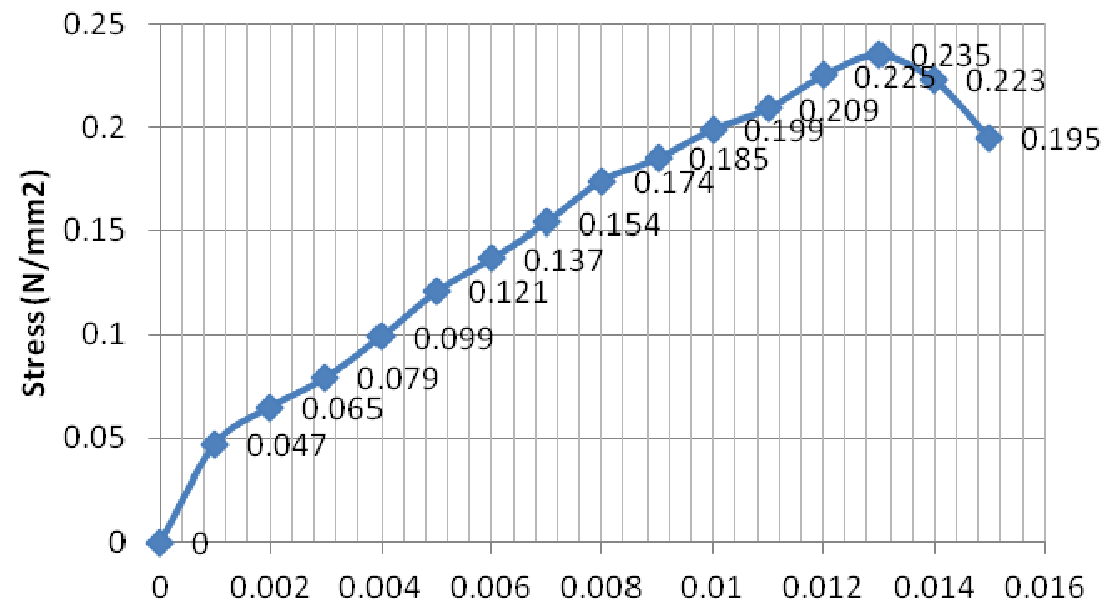

Graph:-Graph between Stress and Strain for KSD (4\%) 
International Journal of Trend in Scientific Research and Development (IJTSRD) @ www.ijtsrd.com eISSN: 2456-6470

III. For $6 \%$ Kota Stone Dust:

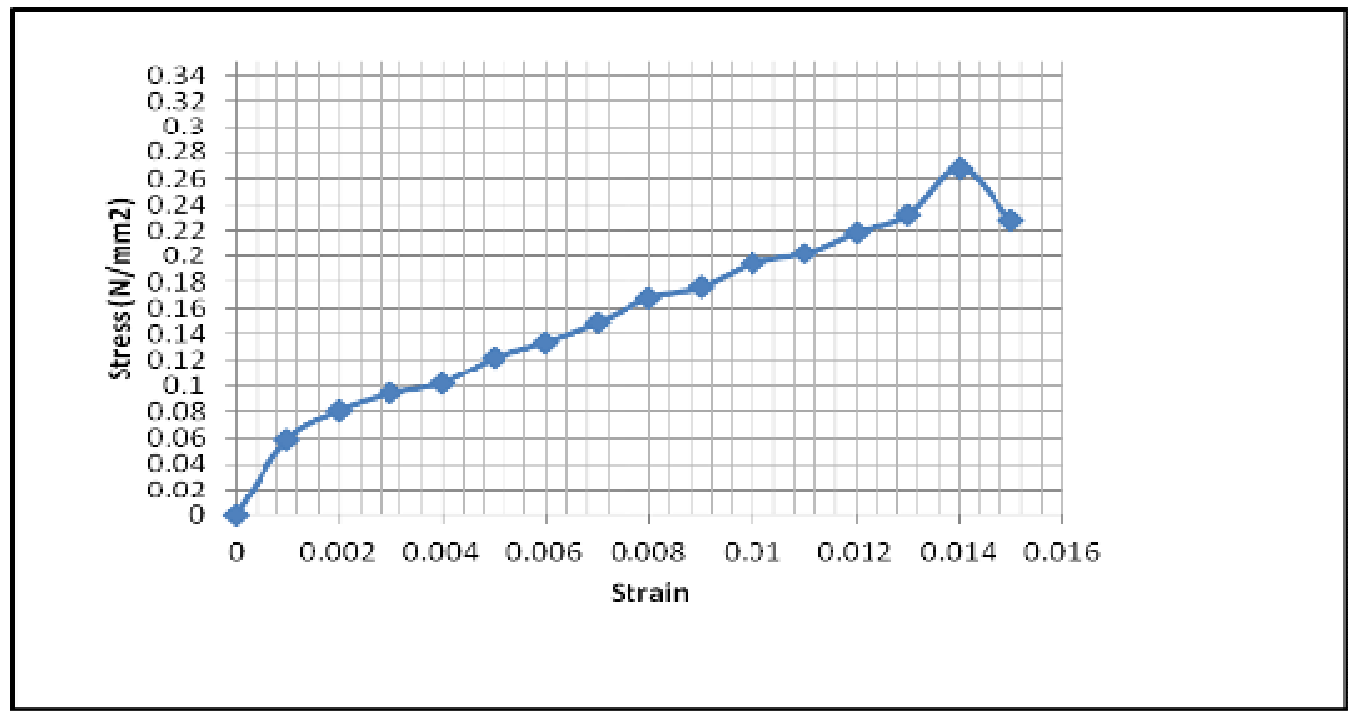

Graph:-Stress and Strain for KSD (6\%)

For 8 \% Kota Stone Dust:

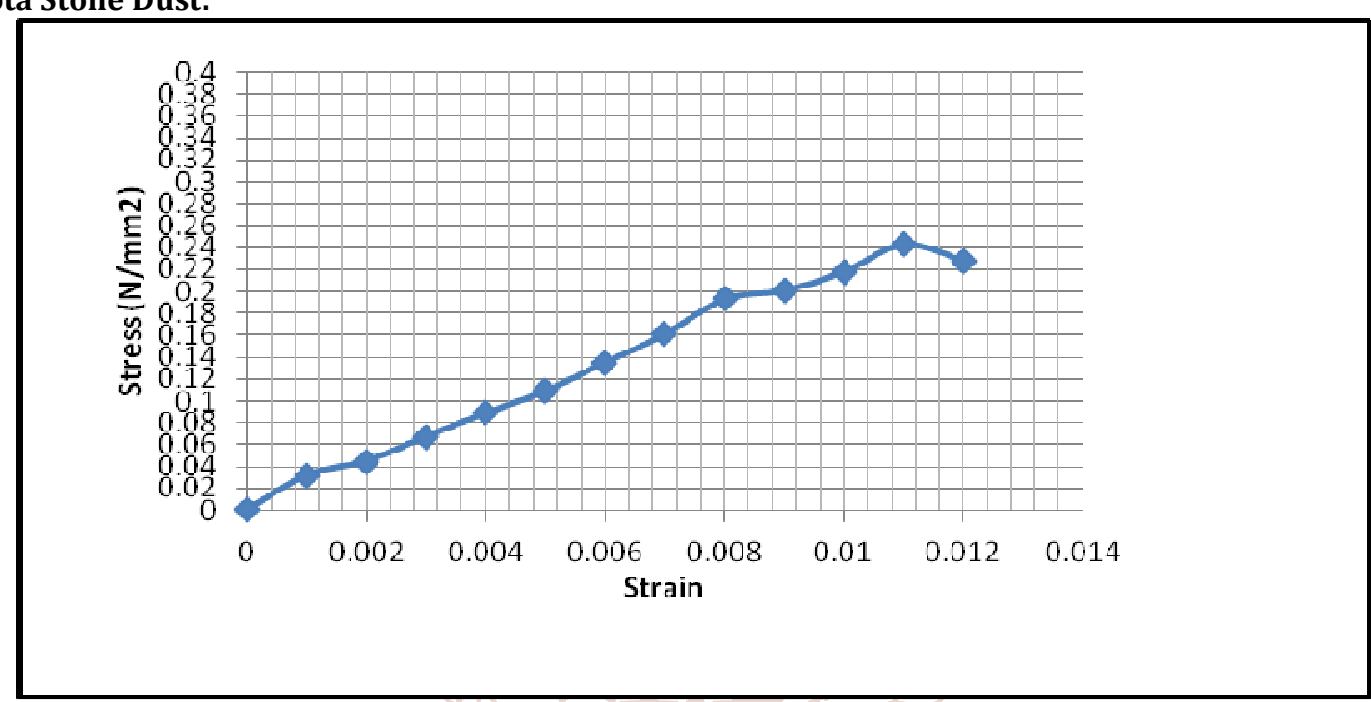

Graph:- between Stress and Strain for KSD (8\%)

IV. For $10 \%$ Kota Stone Dust:

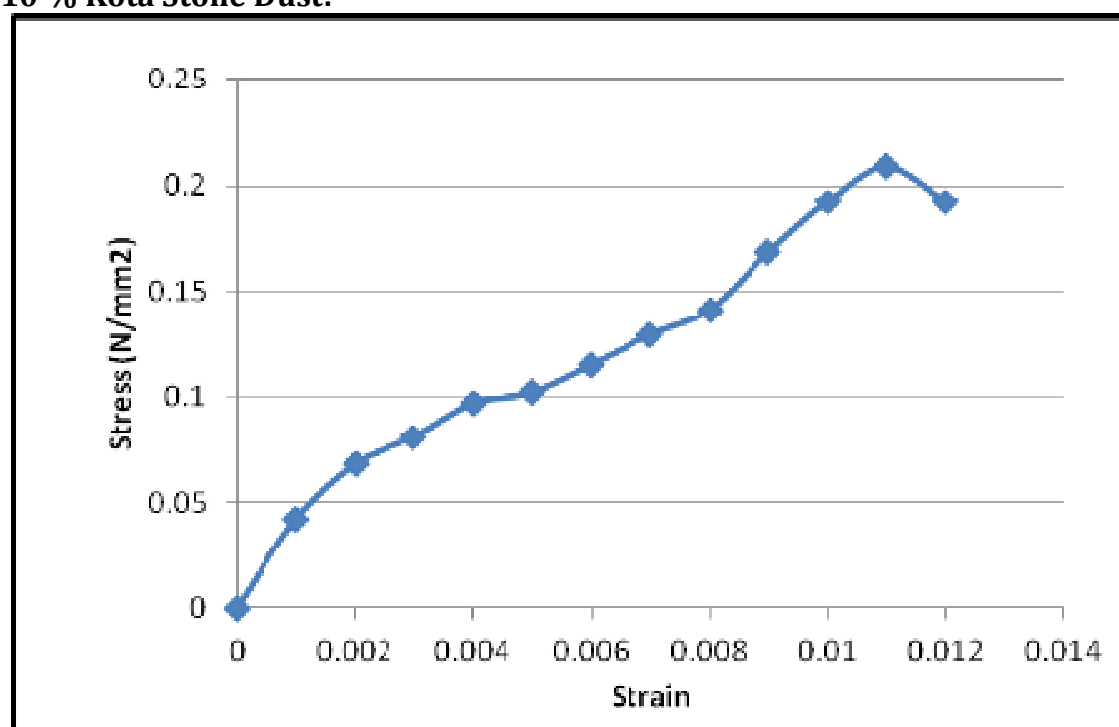

Graph: Stress and Strain for KSD (10\%) 
International Journal of Trend in Scientific Research and Development (IJTSRD) @ www.ijtsrd.com eISSN: 2456-6470

\section{CONCLUSION}

1. Kota Stone show high range of OMC and it maximum dry density is low.

2. We find that when Kota Stone Dust is added in the soil then optimum moisture contains will be increased from $13.80 \%$ to $19.70 \%$. Because in the Kota Stone Dust lime is available so lime absorb the water it moisture contain value increased.

3. We also conclude that when Kota Stone Dust are added in the soil then maximum dry density will be decreased 1.72 to $1.593 \mathrm{~g} / \mathrm{cc}$.

4. We also conclude that by adding Kota Stone Dust are added in the soil then UCS will also increased from $0.213 \mathrm{MPa}$ to $0.274 \mathrm{MPa}$ but after more than $4 \%$ Kota stone Dust are added then strength will not increased.

5. In this research work we conclude that optimum value of Kota Stone Dust will be taken $4 \%$.

6. When percentage of Kota Stone Dust will be increased in the soil then maximum dry density will increased and optimum moisture contained decreased.

\section{REFERENCES}

[1] Rishabh singh and D.S.roy et.al (2018) comparative study of soil stablization with widely used admixtures international journal of engineering trends and technology-volume 58 issue 2 -April 2018

[2] Ankit singh negi , Mohamand faizan et.al.(2018) soil stabilization using lime International Journal of Engineering Research and Science \& Technology ISSN2395

[3] Aakanksha Gautam and S.K, Mittal et al. (2018) "Stabilization of black cotton soil using bagasse ash and coir fibre" International journal advance research ideas and innovation in technology Vol. 4, No. 5, 2018.

[4] Sabat "A Study on Some Geotechnical Properties of Lime Stabilised Expansive Soil - Quarry Dust Mixes" IJETED ISSN 2249-6149Volume 1 Issue 22012

[5] Sabat Akshay, Radhikesh, P.Nanda (2011) "Effect of marble dust and durability of Rice Husk Ash Stabilised Expansive Soil", International Journal of Civil and Structure Engineering volume 1, no 4,2011

[6] AkshaykumarSabat,Radhikesh P. Nanda(2011)"Effect of marble dust and durability of Rice Husk ash stabilized expansive soil", International journal of Civil and structure engineering volume 1, no 4,2011

[7] J. Choobbasti,H. Ghodrat,M. J. Vahdatirad "Influence of using rice husk ash in soil stabilization method with lime" Frontiers of Earth Science in ChinaDecember
2010, Volume 4, Issue 4, pp 471-480

[8] Peethamparan \& Olek,"Study of the Effectiveness of Cement Kiln Dusts in Stabilizing Na-Montmorillonite Clay" volume 21 Issue 112009

[9] Tandel, Yogendra K., (2008), "Utilization of Copper Slag to improve geotechnical properties of soil", M. Tech (SMFE) Thesis, SVNIT, Surat.

[10] Musa Alhassan "Permeability of Lateritic Soil Treated with Lime and Rice Husk Ash" AU J.T. 12(2): 115-120 (Oct. 2008)

[11] Kumar B.“Evaluation of Properties of High-Volume FlyAsh Concrete for Pavements" American Society of Civil Engineers Volume 19 Issue 102007

[12] Bhuvaneshwari, S. and Robinson, R.G., "Stabilization of Expansive soils using Flyash", Fly Ash India 2005, New Delhi, pp. VIII 5.1-5.10.

[13] Kumar,A.V.P.,Ramakrishna,A.N., "Influence of Coffee husk layer on CBR value in Black Cotton Soil”, Highway Research Bulletin, No. 71, December 2004.

[14] Shenbaga\&Havangi "Behavior of Cement-Stabilized Fiber-Reinforced Fly Ash-Soil Mixtures“ JGGE 127 (7) 2001

[15] Subba Rao K.S. (2000) "Swell-shrink Behaviour of Expansive Soils-Geotechnical Challenges", Indian Geotechnical Journal, 30(1), 1-68

[16] Indraratna, B. and Kuganinthira, N. (1991), "Stabilization of Weak Tropical Soils by Fly Ash", Proceedings of Asian Regional Conference on Soil Mechanics \& Foundation Engineering, Vol. 1, Bangkok, Thailand, pp. 491-496.

[17] Petry, T.M and Armstrong, J.C (1989), "STABILISATION of Expansive Clay Soils”, TRR -1219, TRB, pp 103-112

[18] Sharma, M.C (1988), "Lime STABILISATION Used In Construction of Some Roads in Rajasthan", Vol. 16, No. 12, Indian Highways, pp 75-85.

[19] Sivapullaiah, P.V., Sitharam, T. G. and Rao, K. S. Subba "Modified Free Swell Index for Clays", Geotechnical Testing Journal, GTJODJ, Vol. 10, No. 2, June 198780-85.

[20] Sahu,B.K."Improvement of California Bearing Ratio of Various soils in Botswana by Fly Ash", International Ash Utilization Symposium,Center for Applied Energy Research, University of Kentucky, pp. 90. 